\title{
Aspects of protection and social vulnerability of teenagers in public all-day schools
}

\author{
Aspectos de proteção e vulnerabilidade social de adolescentes de escola pública integral \\ Aspectos de protección y vulnerabilidad social de adolescentes de escuela pública a tiempo completo
}

'Universidade Federal de Goiás. Jataí, Goiás, Brazil.

\begin{abstract}
Laurena Moreira Pires'
ORCID: 0000-0002-8052-2479
\end{abstract}

Márcia Maria de Souza"

ORCID: 0000-0003-1467-3866

Marcelo Medeiros"

ORCID: 0000-0001-6979-3211

Universidade Federal de Goiás. Goiânia, Goiás, Brazil.

How to cite this article: Pires LM, Souza MM, M Medeiros. Aspects of protection and social vulnerability of teenagers in public all-day schools. Rev Bras Enferm. 2020;73(Suppl 1):e20190211. doi: http://dx.doi.org/10.1590/0034-7167-2019-0211

\section{Corresponding author:}

Laurena Moreira Pires

E-mail: laurenapires@gmail.com

EDITOR IN CHIEF: Antonio José de Almeida Filho ASSOCIATE EDITOR: Fátima Helena Espírito Santo

Submission: 06-14-2019

Approval: 10-08-2019

\begin{abstract}
Objective: identify and analyze aspects related to social vulnerability of a group of teenagers of a public all-day school with regard to harmful and abusive use of psychoactive drugs. Methods: a strategic social study, with a qualitative approach, was carried out with 49 teenagers of a public all-day secondary school. Focus groups were carried out between 2016 and 2017, and the resulting material was transcribed and analyzed by means of thematic content analysis, resulting in the following categories: The family I come from; Birds of a feather; If I'm studying, how can I work?; Drugs: a non-parallel universe. Results: social vulnerability was associated with unequal income distribution, fragile social relations affected by the harmful use of drugs and vulnerability of public all-day schools. Final considerations: all-day schools did not appear as an effective tool to break away with the context of social vulnerability regarding the use of drugs.

Descriptors: Social Vulnerability; Adolescent; School; Illicit Drugs; Adolescent Behavior.
\end{abstract}

\section{RESUMO}

Objetivo: identificar e analisar aspectos relacionados à vulnerabilidade social de um grupo de adolescentes do ensino público em tempo integral ao uso abusivo e prejudicial de drogas psicoativas. Métodos: pesquisa social estratégica de abordagem qualitativa, desenvolvida com 49 adolescentes de uma escola pública de ensino médio em tempo integral. Os grupos focais foram realizados entre 2016 e 2017 e o material obtido transcrito e analisado por meio da análise de conteúdo modalidade temática, tendo originado as seguintes categorias: a família de onde venho; com quem tu andas; se estudar, como trabalhar?; drogas: universo não paralelo. Resultados: a vulnerabilidade social foi relacionada à má distribuição de renda, à fragilidade das relações sociais permeadas e subsidiadas pelo uso nocivo de drogas e à fragilidade da escola pública em período integral. Considerações finais: a escola em tempo integral não se apresentou como ferramenta significativa para romper com o contexto de vulnerabilidade social ao uso de drogas.

Descritores: Vulnerabilidade Social; Adolescente; Escola; Drogas Ilícitas; Comportamento do Adolescente.

\section{RESUMEN}

Objetivo: Identificar y analizar aspectos relativos a la vulnerabilidad social de un grupo de alumnos adolescentes de escolaridad pública a tiempo completo respecto del consumo abusivo y perjudicial de drogas psicoactivas. Métodos: Investigación social estratégica de abordaje cualitativo, desarrollada con 49 alumnos adolescentes de enseñanza secundaria pública a tiempo completo. Grupos focales realizados entre 2016 y 2017, el material fue transcripto y analizado por análisis de contenido temático, surgiendo las categorías: La familia a la que pertenezco; Con quién andas; Si estudias, ¿cómo trabajas?; Drogas: universo no paralelo. Resultados: La vulnerabilidad social estuvo asociada a la mala distribución de ingresos, debilidad de las relaciones sociales teñidas y respaldadas por el consumo nocivo de drogas y debilidad de la escuela pública a tiempo completo. Consideraciones finales: La escuela a tiempo completo no constituye una herramienta significativa para romper el contexto de vulnerabilidad social frente al consumo de drogas.

Descriptores: Vulnerabilidad Social; Adolescente; Escuela; Drogas llícitas; Conducta del Adolescente. 


\section{INTRODUCTION}

Adolescence is a period of human development that is marked by biological, psychological and social changes, within a historical, social, cultural and economic context in which individuals are found $^{(1-2)}$. It is a period of permanent search for identity, curiosity, experimentation, feelings of omnipotence and objection, with an inherent condition of vulnerability and need for physical, psychic and moral protection, with undivided attention ${ }^{(1)}$.

Of the various situations of vulnerability to which teenagers can be exposed, the use of psychoactive drugs has been described as inherent and present in increasingly young age groups in Brazil. In addition, the inherent characteristics of this development stage maximize the vulnerability of these individuals ${ }^{(2-3)}$.

The vulnerability to psychoactive drugs in adolescence can be particularly maximized in low income and uneducated individuals, with dysfunctional family relationships marked by permissiveness and interactions in environments where the use of drugs is widespread and accepted ${ }^{(3-4)}$.

Studies have pointed out the creation of social ties (family, school or friends) as a protecting factor for the abusive use of psychoactive drugs and other situations of vulnerability in adolescence, with an emphasis on communication with family and schools regarding qualified hearing to deal with situations of suffering, acknowledgment of changes and risk situations when creating a network of care for these individuals ${ }^{(3-5)}$.

This study starts from the social vulnerability concept proposed by Robert Castel, who analyzes the existence of individuals based on two different axes: insertion in the labor market and density of relational insertion in family and socialization networks ${ }^{(6)}$. Relational insertion is defined by the ties created with close family and social groups, and it has a certain importance in the social life of individuals since it allows for a sense of belonging to a community $^{(6)}$. Work, in turn, is the economic, psychological and identity reference, as well as a cultural and symbolic reference in the structuring of their existence, seen as a special support system in the integration to the social structure(6).

From that point of view, social existence is defined by the density of social relations maintained by the individual and their connections with the labor market, allowing for a distinction in four 'zones' of social cohesion: integration, social vulnerability, assistance, and disaffiliation ${ }^{(6)}$. 1) the integration zone is characterized by the association between stable work and solid relational insertion; 2) assistance zone is considered to be a zone in which we find individuals who are not in the labor market as a result of inability, but who, on the other hand, have a solid social insertion obtained by means of assistance schemes; 3 ) social vulnerability is characterized by a random and changing participation in the labor market, associated with fragile and meaningless social relations. When this situation is worsened, it can result in disaffiliation; and 4), disaffiliation, which is the absence of participation in any productive activity and relational isolation ${ }^{(6)}$.

The use and abuse of psychotropic drugs in adolescence leads to individual and collective situations that may affect the individual's physical and psychological health, with a risk of eroding family and community relationships and interfering in their future development ${ }^{(1,5)}$.
On the other hand, the overcoming of this vulnerability is associated with the potential and skills gained by teenagers themselves, as well as by their families and the communities where they live, so they can follow paths that enable them to overcome these difficulties ${ }^{(7)}$.

Robert Castel discusses the need to strengthen individuals and families who are in a condition of social fragility in order to foster their rehabilitation in other social cohesion zones. For this author, the concept of social protection is associated with the individual's rights and elementary independence conditions ${ }^{(7)}$. In modern society, with the weakening of work relationships, social protection becomes a prerequisite in order to shape a truly democratic society of fellow human beings ${ }^{(7)}$.

Thus, over the last decade, programs related to social protection of teenagers have been fostered in the field of education, among which are public all-day schools ${ }^{(8)}$. By its conception, public all-day schools must allow students to participate in activities that compose the Diverse Core, in addition to complying with the core curriculum, common to all Brazilian schools, which is established by the National Curricular Guidelines. Subjects of the Diverse Core are those that carry out activities or workshops for pedagogic supervision, experimentation and scientific research; they are related to culture, sports and leisure, information and communication technologies, human rights, environmental protection, and promotion of health and quality of life. Therefore, their curricula are based on the alternation of classes and extracurricular activities, with the purpose of integrating scientific aspects to the social development of students, assigning educational institutions the mission of educating, protecting, and empowering socially vulnerable children and teenagers ${ }^{(8-9)}$.

The use of psychoactive drugs may, however, undermine relational insertion and also the labor market insertion, leading teenagers to a social vulnerability zone. From the perspective of social vulnerability and protection discussed by Robert Castel, the use of psychoactive drugs among teenagers who are already in the social vulnerability zone can be a means of social life organization, which provides a sense of relational insertion or even of relationship with the labor market ${ }^{(2-3,5)}$.

Since this is a recent perspective of public basic education in Brazil, the role of public all-day schools as a good educational policy has been widely discussed in the scientific world ${ }^{(8-9)}$. On the other hand, the discussion about its potential as an instrument to ensure protection and sound development of children and adolescents who live in very vulnerable environments has been little explored ${ }^{(8-10)}$.

In situations in which program actions related to protection do not meet the actual needs and expectations of teenagers, such as all-day schools, or if groups of relational insertion are not a safe place for coexistence, help, and care, individuals may find it difficult to move to other zones of social cohesion (assistance and integration), thus triggering a process of disaffiliation ${ }^{(3,5)}$.

As social phenomena, the use of drugs and social vulnerability cannot be understood separately, but rather from a perspective that allows for reflection on social, political, economic, and cultural dynamics in which adolescence is consolidated and reflection on the value of protective policies ${ }^{(1-3)}$.

Therefore, analyzing situations of social vulnerability to which they are exposed, in contexts that are intrinsically marked by 
the recreational and harmful use of psychotropic substances, in spite of attending all-day schools, can show ways that lead to the implementation of program measures to protect teenagers, aiming at strengthening the prominence of teenagers and their families in view of the social iniquities they experience.

\section{OBJECTIVE}

To identify and analyze aspects related to the social vulnerability of a group of teenagers of a public all-day school with regard to harmful and abusive use of psychoactive drugs.

\section{METHODS}

\section{Ethical aspects}

Original project from an article approved by the Research Ethics Committee of the Hospital das Clínicas of the Federal University of Goiás, guided by Resolution 466/2012 of the National Health Council. The objectives, the justification, as well as the risks and benefits of the study were explained to participants. Free and informed consent forms were signed by parents or guardians of teenagers under 18, and assent terms were signed by teenagers themselves. Those who were over 18 signed the free and informed consent forms only. In order to respect anonymity, the letter $M$ was used to refer to male participants and the letter $\mathrm{F}$ to refer to female participants, and the respective letter was followed by a number between 1 and 49, representing their order of participation in focus groups.

\section{Theoretical and methodological framework}

This is a social study of strategic nature. Social studies go deeper into the meaning of actual experiences of individuals, of actions and human relationships that are complex objects of historical awareness, and in permanent evolution, involving the world perspective of both social actors and researchers themselves, who are part of the observation process ${ }^{(10)}$.

In a strategic approach, the meanings of a phenomenon (issue) are put into context and explored in the light of the historical process, without necessarily bringing practical solutions to solve it, but fostering future thoughts that objectify its resolution. Thus, based on social sciences theories, it is possible to clarify certain unsolved problems in the scope of society by means of the world perspective of participants of this social system ${ }^{(10)}$.

\section{Type of study}

This is a strategic social study of a qualitative approach. To draft this article, the Consolidated criteria for Reporting Qualitative research (COREQ) was used in order to get an explicit and broad report ${ }^{(11)}$.

\section{Methods}

Data were collected by means of focus groups, by clinical method, carried out from January 2016 to December 2017. Focus groups are a data collection technique that promotes broad problematization and discussion about a studied social phenomenon, by means of group interaction, in order to understand beliefs, feelings, and behaviors ${ }^{(12)}$.

All focus groups were carried out using the same debate script, composed of an adapted diagram taken from a previous study ${ }^{(13)}$, divided into four quadrants: family, work, community, and group of friends. The work quadrant was also divided into two other topics: work and school. Also, a semi-structured script was developed, with topics that guided group discussion: 1) looking at the map, who is in it?; 2) what changes (or could change) people distribution on the map?; 3) can drugs be found on your relationship map?; 4) where can drugs be found on the map?; 5) how is the life of people who have drugs on their map?; 6) how do people from my map react when drugs are on it?

Six focus groups were carried out, with a variable number of participants, from six to 12 . Each meeting lasted approximately 65 minutes, and each student was allowed to participate in one meeting only. The number of focus groups was limited by data saturation.

The researcher in charge moderated focus groups with the help of an assistant who was previously briefed to observe group processes and dynamics, and who recorded speeches and nonverbal language, by means of digital recorders.

\section{Study setting}

The study setting was a state educational institution located in the east of Goiânia, GO (Brazil), a region that is characterized by a low average income, lack of infrastructure and public services, as well as one of the regions with the highest crime and unemployment rates of the municipality. Since 2013 , the institution has provided all-day secondary education and it complies with the prerogatives of the Education Pact promoted by the State Education Secretariat.

The choice for this institution was made because it was eligible with regard to structural and functional aspects, and also because of its interest, involvement and will to carry out the study, in addition to having implemented the School Health Program (SHP) in its Pedagogic and Political Project.

\section{Sources}

Forty-nine teenagers aged between 15 and 19 years old who attended an all-day school (CEPI) participated in the study.

\section{Data collection}

The operationalization of the project named "Assessment of actions carried out in basic education with regard to the use of licit and illicit drugs by students - a prospective cohort study" allowed our researcher to come closer to CEPI, setting of our study, as a teacher of the subject "Health and prevention at school" for three semesters, between January 2016 and December 2017. Experiences and observations made during this period were recorded in a field diary, which allowed for a better understanding of the chosen setting, of the dynamics established, as well as a deep observation of the study object. Therefore, along with this process, data collection also began in the last semester (between August and December 2017). 
Students were invited to participate in the study by the researcher in charge, and they all attended CEPI during class hours, after the objectives and methods were explained. Those who were interested in participating followed the ethical procedures mentioned above.

On the days scheduled for focus groups, students were referred to another classroom so as not to interfere in ongoing activities and to ensure the required privacy so everyone could speak freely, without embarrassment.

Following the pre-established script, the first focus group activity consisted of asking teenagers to fill in the diagram "Relationship Map"(13-14). People considered to be significant at that time were placed in each quadrant. The closer to the center, the more significant they were, and conversely, the farther, the less significant those people were to them.

Afterwards, the researcher began to coordinate the group discussion guided by a script with the triggering questions that we mentioned before.

\section{Data organization and analysis}

All speeches of focus groups were recorded, and observations were made throughout the meetings and recorded in the field diary. For data analysis, a thematic content analysis was carried out and organized around three chronological cores and according to articulated steps: pre-analysis, material exploration and results processing, inferences, and interpretation ${ }^{(15)}$.

Pre-analysis consisted of the full transcription of speeches made during focus groups. The data analysis process started with the exhaustive reading of the resulting material associated with information found in the "Relationship Map" and in the field diary. The analysis of this material and the help of judges allowed for the identification and analysis of the main ideas found in the speeches of participants. Therefore, the main ideas were grouped in meaning cores related to the density of relational insertion and insertion in the labor market, thus resulting in the final theme categories that supported the material analysis based on inferences grounded on the literature and on interpretations supported by the adopted theoretical reference.

\section{RESULTS}

Thirty teenage girls and 19 teenage boys participated in the study, making a total of 49 participants. Four of them reported that they were involved in an activity defined as work during the times they were not at school.

Starting from the categories found in the process of analysis of the qualitative material that resulted from statements and observations recorded in the field diary, the results will be presented in four categories: "The family I come from"; "If I'm studying, how can I work?"; "Drugs: non-parallel universe”.

\section{The family I come from}

In the studied group, the family had different configurations. Single-parent families, with most families headed by mothers, and reconstituted families were the most common.
My family is made of my father, my mother, my sister... (F16, 16 years old)

My father has just gone out for cigarettes! [Justifying the father's absence] (M41, 18 years old)

Then I call my stepfather 'dad', because he has raised me since I was a child. (F17, 16 years old)

Just like my stepmother, who I call 'mother'. (F1, 17 years old)

Yes, I'm close to my stepfather and my father too. (M31, 16 years old)

The importance of the mother figure was widely reported by subjects since mothers were in the first level of closeness in the "relationship map" made by them.

Regarding common life with parents, teenagers were constantly in search of family emancipation. On the other hand, a reference to control, protection, and family authority was noticeable in their speeches.

My father won't let me go. [...] Because it's not a nice place for me. (F38, 16 years old)

I'm not a club member [of a soccer fan group], my mother didn't allow me because I'm under 18. (F9, 17 years old)

And some parents are very permissive. (F18, 16 years old)

My mother doesn't prevent me from anything. (M11, 17 years old)

\section{Birds of a feather}

The school environment was seen as an important setting for relational insertion. Although students belonged to other peer groups who they related to, their speeches showed that all-day schools favor their relational insertion.

Because you spend 10 hours here and you kind of get used to people and to the school routine. (M32, 17 years old)

It's living together. We [pointing at F1] were very different, but we've learned to live together. (M45, 16 years old)

Even if we are not too close, we end up being a family. (F22, 16 years old)

Other groups of relational insertion, such as friends from the neighborhood, soccer club fans, and sports groups were also reported by participating teenagers, but school friends were in the first level of closeness in the "relationship map", which shows their relevance.

With regard to the social context in which they are, the teenagers of this study reported that they looked for a group of friends based on two main reasons: search for protection and search for social identification.

It depends, if they know the person. If they don't, they do steal! But people like me or A3 who are very well known around here, they don't get too close! (M4, 17 years old) 
If he wasn't my friend, he would let the kids kill me. (M3, 15 years old)

And I've talked a lot to A4, I've given some advice. (F2, 16 years old)

Although they acknowledged the transgressive behaviors related to the use and abuse of drugs by groups of friends who they were acquainted with, friendship was protected, regardless of their acts.

Even though I know he's doing wrong stuff, it's hard! [Staying away from a cousin who does drugs] (F30, 19 years old)

A4 is like that, he's cool, you know? But if he hangs out with some boys out there, he gets into trouble. (M5, 16 years old)

I knew he smoked marijuana [...] and I also knew he sold. But I liked him because he was a nice neighbor. (F30, 19 years old)

\section{If I'm studying, how can I work?}

Teenagers expressed their will to enter the labor market as soon as possible, which is explained by their search for emancipation and will to buy consumer goods their parents can't afford. It should be noted that this wish was not related to a need for helping in family income.

At the weekend, the kids say "let's go have a pizza, let's go to McDonald's"; you have your pocket money, you go to a cash machine, get your money, and go! If I ask your mom, she'll give me $R \$ 10.00$ and say: 'Bring the change back!' (M11, 17 years old)

I've got everything, but I want more! I'm not lacking in anything, but... (F36, 17 years old $)$

I want to leave [mother's] home and have my own stuff. (F9, 17 years old)

However, for these teenagers, all-day schools are a barrier to the so much wanted labor market insertion.

I'm going to leave, I want to study half-time only. [...] because I want to get a job. (F44, 17 years old)

We won't have time to do the activities and we will be more focused on our jobs than on our studies. This will be a disturbance and we will drop out of school. (F1, 17 years old)

Well, study to go to college and get a job, and then go to college in the evenings and make money. (F16, 16 years old)

\section{Drugs: a non-parallel universe}

In the studied group, the routine of settings to which they belonged was characterized by the harmful use of drugs, in both the streets and leisure environments and in the borders of reference social institutions: family and school.

There's a crack house opposite to my house. (M28, 17 years old)

Indeed, the square is the easiest place [square next to the school]. (M40, 16 years old)
Lots of drug dealers in my family. (M3, 15 years old)

It also happened to me, I was leaving the school and there were lots of drug addicts around that corner [pointing at the school wall], even sniffing paint thinner. (M31, 16 years old)

Alcohol, tobacco, and marijuana were the drugs mentioned by the teenagers as the most used ones. Therefore, since this view was shared by everyone around them, access to psychoactive drugs was commonplace to them.

There are so many stories that you end up getting used to it! (M32, 17 years old)

Regular people do drugs, right? (M11, 17 years old)

It's like marijuana, some people see somebody smoking and goes: Oh my God, they are smoking..." but now it's so ordinary! Then it will happen with cocaine, crack, ecstasy...it will be something normal... (F29, 18 years old)

Oh, it's alcohol every day! (M28, 17 years old)

Generally speaking, the teenagers reported that a life story filled with harmful use of psychoactive drugs is related to potential peer pressure, but on the other hand, it implies a risk of breaking emotional ties, resulting in social and family isolation, which can lead to disaffiliation.

It depends on the person, if people like him or her, they will get closer, otherwise, they will drift apart. (F30, 19 years old)

My father used to do drugs, and because of this, my parents are no longer together. (F17, 16 years old)

Well, I already knew he smoked, I would ask him to stop, but he had never smoked next to me, you know? But then he got really involved with some weird friends, so we broke up! (F29, 18 years old)

\section{DISCUSSION}

Comprehensive care of adolescents requires measures that cannot be dissociated from global action, since political, social, and economic aspects related to health must be considered ${ }^{(16)}$. The teenagers of this study are following paths that take them to a social vulnerability zone, which goes beyond their context of relational insertion and is worsened by the typical nature of this period of life ${ }^{(6,17)}$. In addition, the macro context is characterized by difficult access to consumer goods, the harmful use of psychoactive drugs and all forms of violence, all of which have negative effects on this adolescent population ${ }^{(15)}$.

Generally speaking, the data collected point out to the drug issue, even though it is not so central. Essentially, they bring to light the relationship between the teenagers' social reality, in which psychoactive drugs are somehow part of, and the conditions related to the harmful use of these substances, such as violence and crime. Thus, it is possible to notice that, according to the teenagers, these issues have a direct effect on relational insertion. In that sense, speeches and observations made during 
data collection reinforce the idea that relational insertion of teenagers happens mainly within the family, in their groups of friends, and at school.

According to the participants, the first and second categories are related in the sense that families, regardless of their configuration, are the first group in which teenagers live, with a key role in their growth and development. In that sense, the family environment fosters relational insertion and, consequently, social development of teenagers ${ }^{(2,4,17)}$.

Although the family structure is important, parenting style is closely related to the density of teenagers' relational insertion in the family and to what it actually means $s^{(2,18-19)}$. The transcribed speeches above show that when parents or guardians assert their responsibility upon teenagers they are respected, indicating that there is no defiance or insubordination.

An open and friendly family, with defined boundaries, adequate communication, which promotes affection and protection, becomes a protecting and stimulating factor for coming of age at this period of life. On the contrary, an unfriendly family, with poor communication and unclear boundaries can favor exposure to risk situations and hamper teenagers' development and self-esteem.

Based on the chosen reference, it is possible to observe in these teenagers' paths, the influence of social and economic contexts in which they are, where the available paths are already determined. Therefore, the creation of relationship networks, although being surrounded by the abusive and harmful use of psychoactive drugs, favors social promotion and allows for social insertion $^{(15,20)}$.

With regard to relationships in groups of friends, it was found that they defined the way how teenagers enter a social context of violence, difficult access to consumer goods, family vulnerability and dissemination of psychoactive drugs, the latter being trivialized and found on a daily basis.

In contexts where the use of psychoactive drugs is widespread, stereotypes and misconceptions about drug addicts, such as participation in violent events, school evasion and withdrawal, are took over and reconstructed by these individuals as a means of enabling their social existence ${ }^{(21)}$. In the fourth analysis category, the teenagers reported that when individuals adopt deviant behavior, such as the use of psychoactive drugs, they drift apart from significant social relationships and become a non-productive workforce, coexisting socially as deviants ${ }^{(5)}$.

The reality in Brazil suggests a certain weakness of education institutions with regard to their role as an empowerment space for individuals to face their social vulnerability situations ${ }^{(5,22-23)}$. In public all-day schools, some weaknesses have been pointed out that put the proposed model at risk, such as the lack of prominence of adolescents, with learning restricted to what teachers teach, mostly inadequate infrastructures and the lack of human, financial, and material resources to support the philosophical concept of all-day education ${ }^{(10,23-24)}$.

All-day schools must be more than just an extended stay at school; they need to be an environment of protection and development of individual features that are necessary to deal with the social vulnerability to which teenagers and families are exposed. However, for these teenagers, schools do not meet their actual needs and expectations, and are actually more a barrier than a place to learn how to enter the labor market in the near future. In addition, if families do not serve as a space of protection, help, and care, vulnerabilities will be maximized.

Regarding the importance of work in structuring social existence of individuals, teenagers from this study looked forward to an early insertion in the labor market since they appreciate having purchasing power. Therefore, since they do not have their own means and their families do not have a purchasing power that is in line with their needs, combining a job with their studies was an option that was frequently mentioned by the group.

Early insertion of teenagers in the labor market can lead to different consequences. An adequate job can result in development and improvement of skills, responsibilities and resources that will be useful throughout their lives. On the other hand, it can also hamper important development stages and result in precocious adulthood, due to the responsibilities required by the labor market, as well as jeopardize academic development because of double shifts, or even result in school evasion ${ }^{(25)}$.

In the context of all-day schools, the insertion of teenagers in the labor market draws them away from school, as reported in speeches. Although it is possible to combine work and study (double shifts) in regular schools, the teenagers themselves reported some difficulties and warned about a possible low performance and potential school evasion.

Therefore, for the participants of this study, the fact that they attend an all-day school is not a relevant tool to break away from the social vulnerability context to which they are exposed since it does not ensure them a satisfying work relationship.

\section{Study limitations}

Although the drug use issue may be considered difficult to address in a school setting, being on the field for 18 months allowed for a close relationship between the involved subjects (researcher, teenagers, teachers, and management). We believe that these ties favored the approval of the researcher and consequently the participation of students, considering that out of a total of 138 students who were finishing their school year at CEPI, 49 participated in focus groups.

Our study has limitations, such as the difficulty in requesting parental permission for students' participation, due to their lack of involvement in their children's school life. Regarding data, the period during which focus groups were carried out (end of school semester) may have had an influence on their reports of wanting to leave all-day school, given their weariness and the dissemination of final grades, with some students being already aware they were going to retake exams.

\section{Contributions to nursing}

During the immersion process, it was possible to observe the lack of participation of families in the lives of those teenagers, as well as the absence of participation of the Family Health Team (FHT) as a supporting institution, even in the School Health Program (SHP), which is prescribed in all-day schools.

Although SHP does not acknowledge nurses as the only actors in charge of the implementation of health actions within 
schools, their presence makes it possible and is key to health promotion processes. The challenge lies in effectively bringing FHT closer, especially nurses, in order to make it the link between families and schools with regard to teenagers' care and assistance. Strengthening these social groups in collective work would acknowledge and establish protective and developing actions so teenagers are able to deal with adversities related to relational insertion and access to the labor market, which undermine the social context in which they are.

\section{FINAL CONSIDERATIONS}

The period during which we were immersed in the CEPI and the process of data collection and analysis reached the proposed goals. The performance of focus groups showed to be an effective tool to find out with participants the meaning they gave to situations they frequently experience.

Social vulnerability reported by participating teenagers is related to the effects of a poor income distribution, which is translated into precariousness and insecurity for professional insertion, along with weak social relationships that are affected by the harmful use of psychoactive drugs. With regard to all-day schools, the teenagers reported that they affect and hamper their professional insertion.

In terms of protection policies, which have been recently implemented and widespread, all-day schools did not prove to be a relevant institution, according to participants, neither a tool capable of breaking away with the social vulnerability to which they are exposed. Although they are not only related to teenagers but also to families, the assumptions about social vulnerability, according to Robert Castel, are clearly present within individuals who attend all-day schools, even if the potential transforming agent is used to justify it.

Since the interventions are made with populations living in a situation of social vulnerability, the fight against disaffiliation points out to the need for making protecting measures for teenagers effective, so as to promote the development of these individuals and of their families in view of the iniquities of the labor market. In that sense, it will be possible to reduce inequalities and poverty, to increase opportunities for all and to act upon determining and conditioning factors for health.

In terms of protection policies, in addition to educating citizens, schools should be referred to as a transforming agent of reality. Therefore, as it was shown by our study, all-day schools must be redesigned so as to be a solid protection tool, thus consolidating themselves as the way to the empowerment teenagers need to break away with negative situations that surround them.

\section{FUNDING}

Fundação de Amparo à Pesquisa do Estado de Goiás (FAPEG).

\section{REFERENCES}

1. Bittencourt ALP, França LG, Goldim JR. Vulnerable adolescence: bio-psychosocial factors related to drug use. Revista Bioética. 2015;23(2):311-9. doi: 10.1590/1983-80422015232070

2. Silva MAI, Mello FCM, Mello DF, et al. Vulnerabilidade na saúde do adolescente: questões contemporâneas. Ciênc Saúde Coletiva. 2014;19(2):619-27. doi: 10.1590/1413-81232014192.22312012

3. Reis AAC, Malta DC, Furtado LAC. Challenges for public policies aimed at adolescence and youth based on the National Scholar Health Survey (PeNSE). Ciênc Saúde Coletiva. 2018;23(9):2879-90. doi: 10.1590/1413-81232018239.14432018

4. Lazari AH, Hungaro AA, Okamoto ARC, Suguayama P, Marcon SS, Oliveira MLF. Famílias em território vulnerável e motivos para o não uso de drogas. Rev Eletrôn Enferm. 2017;19:a11. doi: 10.5216/ree.v19.38380

5. Henriques BD, Reinaldo AMS, Ayres LFA, Lucca MS, Rocha RL. The use of crack and other drugs: the perception of family members in relation to the support network in a reference Center. Ciênc Saúde Coletiva. 2018;23(10):3453-62. doi: 10.1590/1413-812320182310.13462016

6. Castel R. As metamorfoses da questão social: uma crônica do salário. 11a. ed. Petrópolis: Vozes, 2013.

7. Filgueiras CAC, Souki LG. Individualização da incerteza: direito condicionado e ativação da proteção social. Rev Soc Estado. 2017;32(1):89114. doi: $10.1590 /$ s0102-69922017.3201005

8. Zucchetti TD, Moura EPG. Educação integral. Uma questão de direitos humanos? Ensaio: Aval Pol Públ Educ. 2017;25(94):257-76. doi: 10.1590/s0104-403620170001000010

9. Coelho LMCC, Maurício LV. Sobre tempo e conhecimentos praticados na escola de tempo integral. Educ Realidade. 2016;41(4):1095-112. doi: 10.1590/2175-623660673

10. Silva MCG. A educação integral: a escola como direito na perspectiva da humanização e da cidadania. Filosof Educ. 2018;10(1):136-53. doi: 10.20396/rfe.v10i1.8652002

11. Minayo MCS. Pesquisa Social: teoria, método e criatividade. 30a. ed. Rio de Janeiro: Editora Vozes, 2011. 114p.

12. Tong A, Sainsbury P, Craig J. Consolidated criteria for reporting qualitative research (COREQ): a 32-item checklist for interviews and focus groups. International J Qual Health Care [Internet]. 2007 [cited 2019 Jun 10];19(6):349 -357. Available from: https://academic.oup.com/ intqhc/article/19/6/349/1791966

13. Kinalski DDF, Paula CC, Padoin SMM, Neves ET, Kleinubing RE, Cortes LF. Focus group on qualitative research: experience report. Rev Bras Enferm. 2017;70(2):424-9. doi: 10.1590/0034-7167-2016-0091 
14. Sluzki C. A rede social na prática sistêmica. São Paulo: Casa do Psicólogo, 1997. 145p.

15. Pereira SEFN. Crianças e adolescentes em contexto de vulnerabilidade social: articulação de redes em situação de abandono ou afastamento do convívio familiar. Aconchego-DF. 2013;1(1):1-21. Available from: http://acolhimentoemrede.org.br/site/wp-content/ uploads/2016/08/Artigo-sobre-a-REDE.pdf

16. Bardin L. Análise de Conteúdo. 70a. ed. São Paulo: Livraria Martins Fontes, 2011. 280p.

17. Luz RT, Coelho EAC, Teixeira MA, Barros AR, Carvalho MFAA, Almeida MS. Mental health as a dimension for the care of teenagers. Rev Bras Enferm. 2018;71(suppl 5):2212-9. doi: 10.1590/0034-7167-2016-0192

18. Castel R. A dinâmica dos processos de marginalização: da vulnerabilidade a "desfiliação". Caderno CRH [Internet]. 1997 [cited 2019 Jun 10];(26/27):19-40. . Available from: https://portalseer.ufba.br/index.php/crh/article/view/18664/12038

19. Morello P, Pérez A, Peña L, Braun SN, Kollath-Cattano C, Thrasher JF, et al. Risk factors associated with tobacco, alcohol and drug use among adolescents attending secondary school in three cities from Argentina. Arch Argent Pediatr. 2017;115(2):155-8. doi: 10.5546/aap.2017. eng.155

20. Becker KL. O efeito da interação social entre os jovens nas decisões de consumo de álcool, cigarros e outras drogas ilícitas. Estud Econôm. 2017;47(1):65-92. doi: 10.1590/0101-416147136klb

21. Castel R. As armadilhas da exclusão. In: Castel R, Wanderley LEW, Wanderley LEW. Desigualdade e Questão social. 3a. ed. São Paulo: EDUC; 2010. 21-54p.

22. Oliveira E, Soares CB, Batista LL. Everyday representations of young people about peripheral areas. Rev Bras Enferm. 2016;69(6):1147-53. doi: 10.1590/0034-7167-2016-0387

23. Pereira APD, Paes ÂT, Sanchez ZM. Factors associated with the implementation of programs for drug abuse prevention in schools. Rev Saude Publica. 2016;50:44. doi: 10.1590/S1518-8787.2016050005819

24. Campeiz AF, Oliveira WA, Fonseca LMM, Andrade LS, Silva MAl. A escola na perspectiva de adolescentes da Geração Z. Rev Eletron Enferm. 2017;19:a58. doi: 10.5216/ree.v19.45666

25. Dutra-Thomé L, Pereira AS, Koller SH. O desafio de conciliar trabalho e escola: características sociodemográficas de jovens trabalhadores e não-trabalhadores. Psic: Teor Pesq. 2016;32(1):101-9. doi: 10.1590/0102-37722016011944101109 